\title{
ANATOMICAL PROPERTIES AND FIBER DIMENSION OF PRICKLY ACACIA (Acacia nilotica L.) FROM BALURAN NATIONAL PARK
}

\author{
Krisdianto ${ }^{1}$ and Ratih Damayanti ${ }^{1,2}$
}

\begin{abstract}
Acacia nilotica (L.) Willd. ex. Delile growing in Baluran National Park has dramatically altered the ecological balance of grasslands and thereby threatens the existence of local biodiversity. Prickly acacia is able to spread rapidly and remains uncontrollable. Baluran National Park authorization has been struggling to control this prickly acacia trees. One possible action that can be taken to encounter this problem is allowing wood based industries, and local people take advantages of this nilotica timber utilization. This paper studies the anatomical properties and fiber dimensions of nilotica timber and discusses the possible utilization of nilotica timber. This timber is characterized by dark brown heartwood which is clearly distinct from reddish brown color of sapwood. The denser cell wall shows attractively streaked in tangential surfaces. The length of wood fiber decreases from pith toward periphery portion. Longitudinally, higher stem has shorter fiber. Nilotica wood has second class quality of fiber, which means its fiber is moderately thick with narrow lumen diameter. Due to small log diameter and branches, the nilotica timber is not recommended for construction material. The timber is suitable for carved and turnery products. Nilotica timber is suitable for charcoal manufacture and fuel wood due to its high calorific value.
\end{abstract}

Keywords: Acacia nilotica, wood anatomy, fiber, utilization

\section{INTRODUCTION}

Acacia nilotica (L.) Willd. ex. Delile is an exotic acacia species native to India, Pakistan and much of Africa. Nine subspecies are currently recognized and widely distributed in tropical and subtropical Africa extending from Egypt and Mauritania to South Africa (Brenan, 1983). Due to its ecological, economic, and social impacts of this thorny shrub, prickly acacia has been recognized as Weed of National Significance (WONS) in Australia and it becomes one of Australia's worst weeds (Spies and March, 2004).

In Baluran National Park, A. nilotica from Africa has been developed in order to isolate savanna from fire that frequently happens in savanna Bekol. Nilotica mature trees are classified as highly fire resistant trees (Carter, 1994). However, after several years, this prickly acacia has dramatically altered the ecological balance of grasslands and thereby threatens the existence of local biodiversity. Trees compete with grasses for limited soil moisture, thereby reducing food supply and increasing animal pressure on the remaining pasture, particularly the palatable perennial grasses. The infestation of nilotica trees leads to reduction in ground

${ }^{1}$ Forest Products Research and Development Center, Jalan Gunung Batu No. 5, Bogor

${ }^{2}$ Corresponding author. E-mail: Ratih-Damayanti@fforda.mof.org 
cover at the beginning of the growing season, putting maximum pressure on new grass tillers and seedlings. As a result, land degradation is one significant impact from prickly acacia plantation.

Carter (1994) reported that prickly acacia was able to spread rapidly due to some characteristics of its own, such as seedlings and young trees, which were unprotected from grazing by thorns; large seed production up to 175,000 seeds/tree; long lived seeds; the young plants able to grow rapidly; being tolerant of grazing, drought, fire and salinity; long lived trees (30-60 years); and tree growth possible over extensive climatic change.

Baluran National Park authorization has been struggling to control this prickly acacia trees. However, there long-lived seeds make the acacia growing more uncontrollable. Prickly acacia fruit seedling has been eaten by animal and its manure has been a seedling vector for this acacia spread. This thorny plant has spreaded in Bekol savanna and formed homogeny forest like nilotica trees (Sumayku, 2003).

The easiest way to control nilotica tree is to burn them. However, it is not easy as the tree is fire resistant and the fire must be controlled so that it will not spread along the grasslands. Another option to control this tree is allowing wood based industries and local people take advantages of this nilotica timber utilization. However, the study on properties of this timber is needed to provide information on its utilization as currently there is no such information available. If information on its utilization is available for the industry and community, then economical values can be obtained from this timber. This paper studies the anatomical properties and fiber dimensions of nilotica timber and discusses the possible utilization of nilotica timber.

\section{MATERIALS AND METHODS}

Nilotica timber sample was taken from two trees growing in Bekol savannah, Baluran National Park, Eastern Java. Wood samples in the form of $7 \mathrm{~cm}$ length discs were taken from three heights: bottom, medium and top of the log. In each height, samples for fiber maceration were taken from five parts horizontally between the pith and the bark as shown in Figure 1.

Sample blocks were also prepared from the tree log using sample preparation method as reported by Fujii (1989). As many of tree block sections taken from heartwood were each assigned for examination of anatomical features properties on consecutively cross-sectional (transverse), radial and tangential surfaces of the block. The block section of sample for such anatomical feature examination were at first air-dried and then soaked in distilled water for about one week. After being saturated, the samples were then transferred into a container containing solution of etronol-glycerin 1:1 and further kept for about one week before sectioning.

The observed characters with respect to the anatomical features were based on IAWA Committee list (Wheeler et al., 1989). Some of the features were quantitative data. The quantitative data in this study were a representation of first performing 30 measurements on certain features of each investigated sample, and then taking average of them. The quantitative features include vessels (diameter, length, frequency per sq. cm), rays (height, frequency per $\mathrm{mm}$ ) and fibers (length, diameter, wall thickness). 


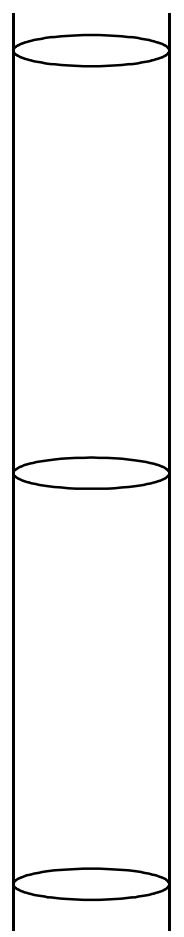

Tree $\log$
Top

Middle
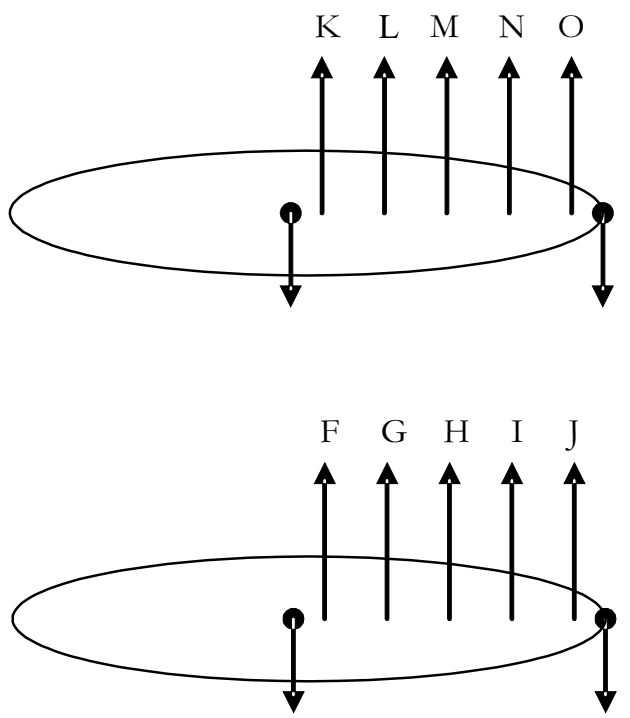

Bottom

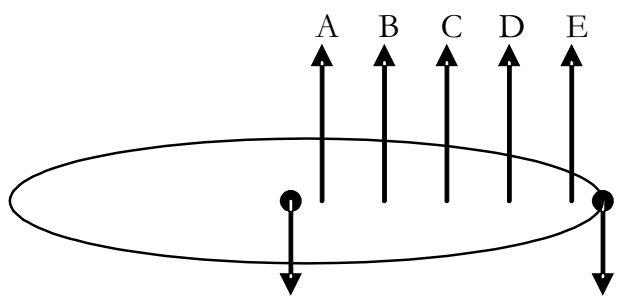

Pith

Bark

Figure 1. Cutting sample pattern for macerated samples

The quantitative data of fibers dimension and vessels length were measured from the macerated samples, and their preparation before maceration is as described in Figure 1. In this regard, the associated wood samples were macerated based on modified Schulze methods (Tesoro, 1989). The sample materials were heated slowly at $40-60^{\circ} \mathrm{C}$ in the mix fuse of concentrated nitric acid and hydrogen peroxide in ratio of 1:1. The heating took about 12 hours to produce adequately macerated material or a satisfactory separation of wood fibers for further dimensional examinations. The qualification of fiber dimensions was based on Rachman and Siagian (1976) criteria. 


\section{RESULTS AND DISCUSSION}

\section{A. Anatomical Properties}

\section{General characteristics}

Color: heartwood is dark brown turning to black, which is clearly distinct from reddish brown of sapwood. Figure: flat sawn board fine and lustrous, the denser and lighter part of the wood cell wall shows attractively streaked in tangential surfaces. Texture: rather fine. Grain: shallowly interlock. Hardness: wood is very hard.

\section{Anatomical properties}

Growth ring : distinct marked by defined growth zones and thin banded parenchyma. $V$ essel: diffuse, solitary and radial multiples of $2-4$, moderate in size of $270.98 \pm 51.46 \mu \mathrm{m}$ in tangential diameter; length $507.3 \pm 6.6 \mu \mathrm{m}$, vessel frequency $4 \pm 0.4$ per $\mathrm{mm}^{2}$, perforations simple; inter vessel pits vestured, alternate to elongated diameter $8.9 \pm 0.9 \mu \mathrm{m}$ in diameter; vessel-ray and vessel parenchyma pits are similar in type and size to intervessel pits; tyloses and substances were rarely found in the vessels. Parenchyma: sparse to moderately abundant paratracheal, vascicentric, usually in prominent sheaths, $2-4$ cells wide around the pores, tending to aliform particularly around the smaller pores in $2-4$ celled strands. Rays: $4.3 \pm 0.2$ rows / $\mathrm{mm}, 1-4$ seriate, an average of $1.015,9 \pm 86,8 \mu \mathrm{m}$ high, up to 40 cells high. Silica bodies absent. Fibers: without septate, $1,554.03 \pm 86.15 \mu \mathrm{m}$ in length; fiber diameter $36.6 \pm 0.4 \mu \mathrm{m}$; lumen diameter $2.2 \pm 0.05 \mu \mathrm{m}$ and fiber pits is about $3.8 \pm 0.2 \mu \mathrm{m}$ in diameter. Material inclusion: prismatic crystals are found in chambered parenchyma strands. The anatomical structure of nilotica is shown in Figure 2, while thick cell walls and intervessels pit are shown in Figure 3 and 4, respectively. 
a.

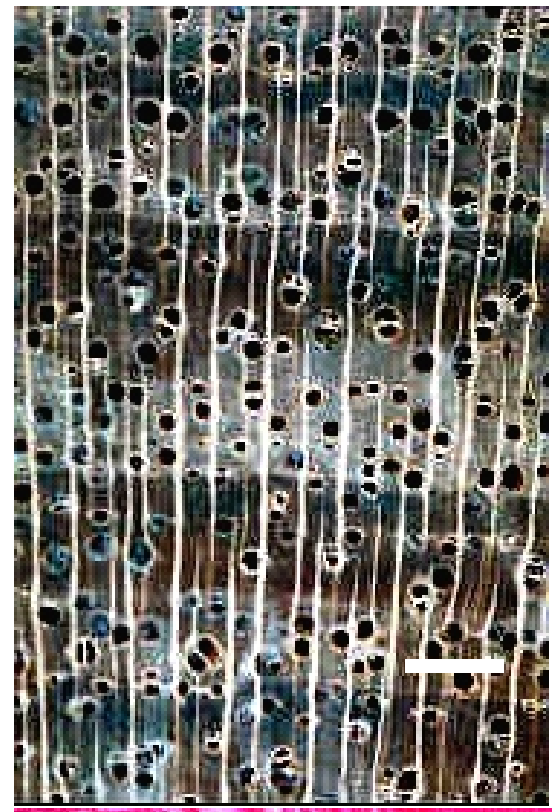

c.

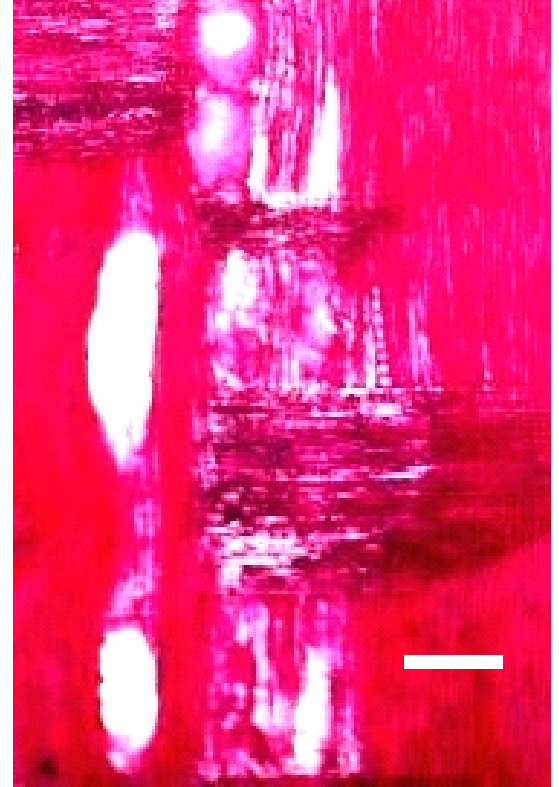

b.

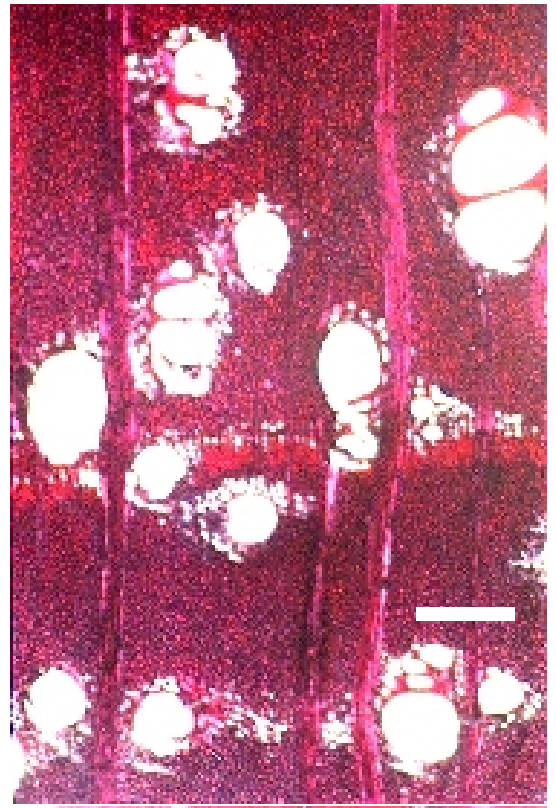

d.

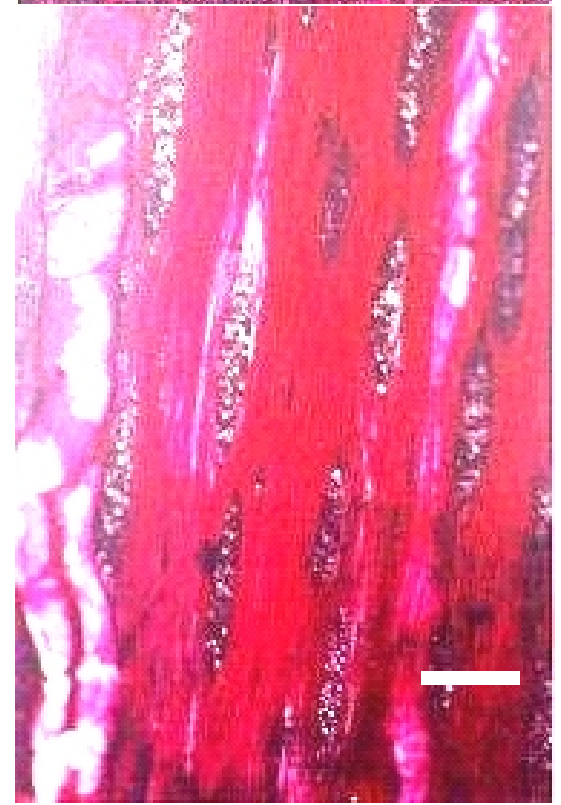

Figure 2. Surface of A. nilotica (L.) Willd. ex Delile
a. Transverse surface, scale bar $=1 \mathrm{~mm}$;
b. Transverse surface, scale bar $=200 \mu \mathrm{m}$;
c. Radial surface, scale bar $=200 \mu \mathrm{m}$;
d. Tangential surface, scale bar $=200 \mu \mathrm{m}$. 


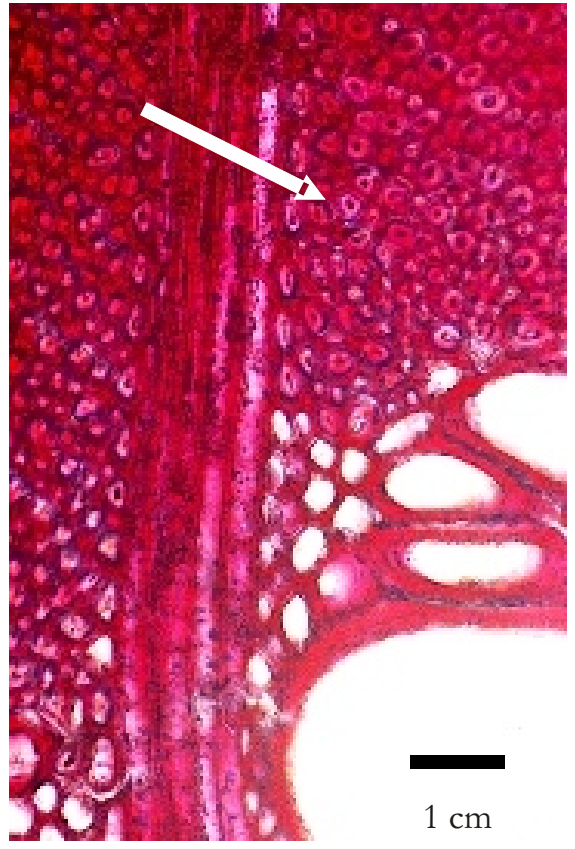

Figure 3. Thick cell walls shown in transversal section, scale bar $80 \mu \mathrm{m}$

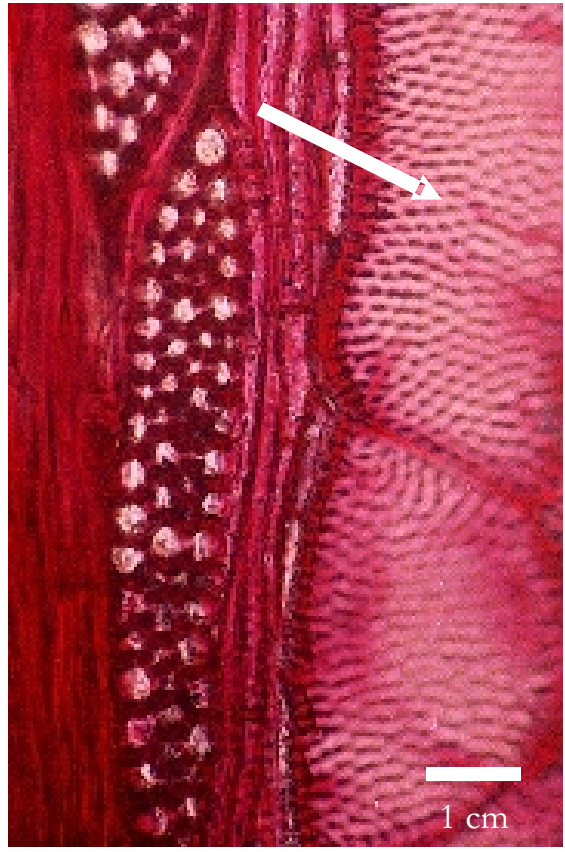

Figure 4. Intervessels pit shown in tangential section, scale bar $80 \mu \mathrm{m}$

\section{B. Fiber Dimensions}

The average fiber lengths of $A$. nilotica from three different heights and five horizontal depth in every disc are shown in Figure 5. The t-test result showed significant differences between mean in every disc. Generally, the disc from bottom part of the tree has longer fibers than those of middle and top discs. The average fiber length from the bottom disc is 1,561.99 $\mu \mathrm{m}$, while the length from middle and top is about $1,551.22 \mu \mathrm{m}$ and $1,531.6 \mu \mathrm{m}$ respectively.

In every disc, the fiber length pattern horizontally is almost similar to the vertical pattern on above. The length of wood fiber decreases from pith toward periphery. The shortest fiber is found in the samples that was taken near the pith, while the longest fiber is the one taken from periphery. Mean comparison between samples taken from pith toward periphery shows significant differences. In the overall discs, the longest fiber up to $1,706.74 \mu \mathrm{m}$ is found in the samples that was taken from bottom near periphery. The phenomena of shorter fiber length from bottom to top and from pith toward periphery was also mentioned by Jane (1970). 


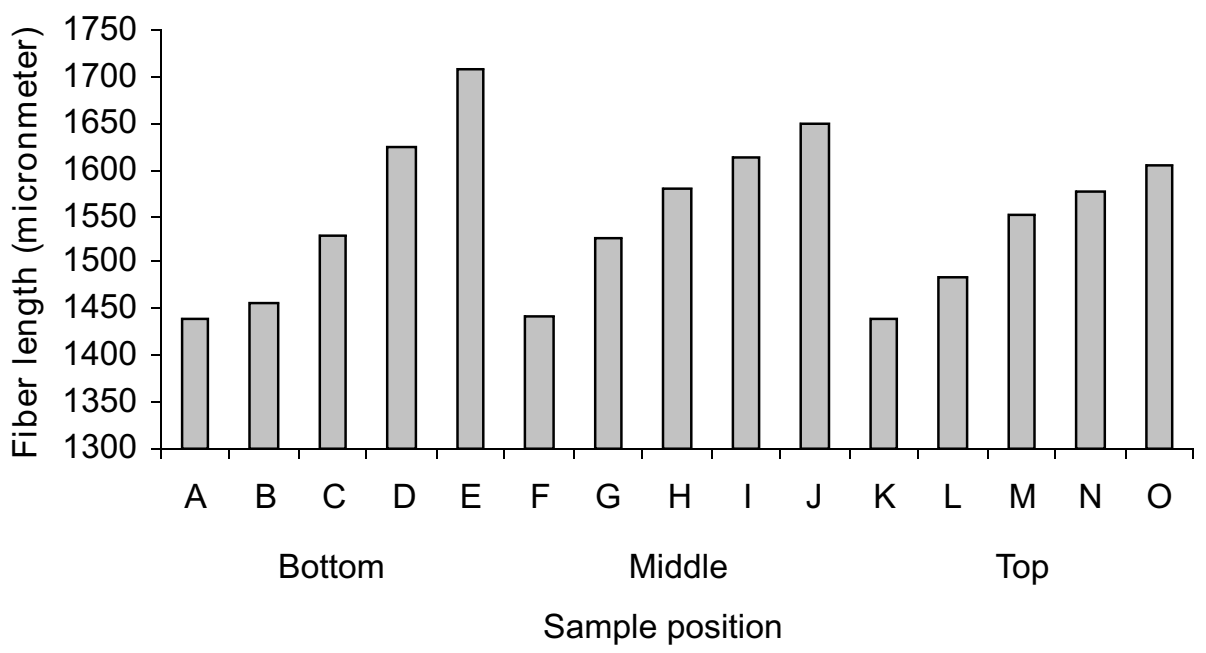

Figure 5. Fiber length of $A$. nilotica

The fiber quality of nilotica timber based on criteria stated by Rachman and Siagian (1976) is shown in Table 1. The fiber quality is assigned from fiber length, Runkel ratio, flexibility ratio, felting power, coefficient of rigidity and Muhlsteph ratio. Fibers of middle and top of the disc are in second class quality, while fibers in three samples from five of that taken from bottom disc fall into third class quality. Overall, fiber quality of nilotica is in the second class quality, which means wood fiber is moderately thick with narrow lumen diameter. During pulp and paper processing, the fiber is easily flattened and interfiber bonding is relatively high. In terms of tear strength the paper from this timber is relatively moderate (Rachman and Siagian, 1976). 


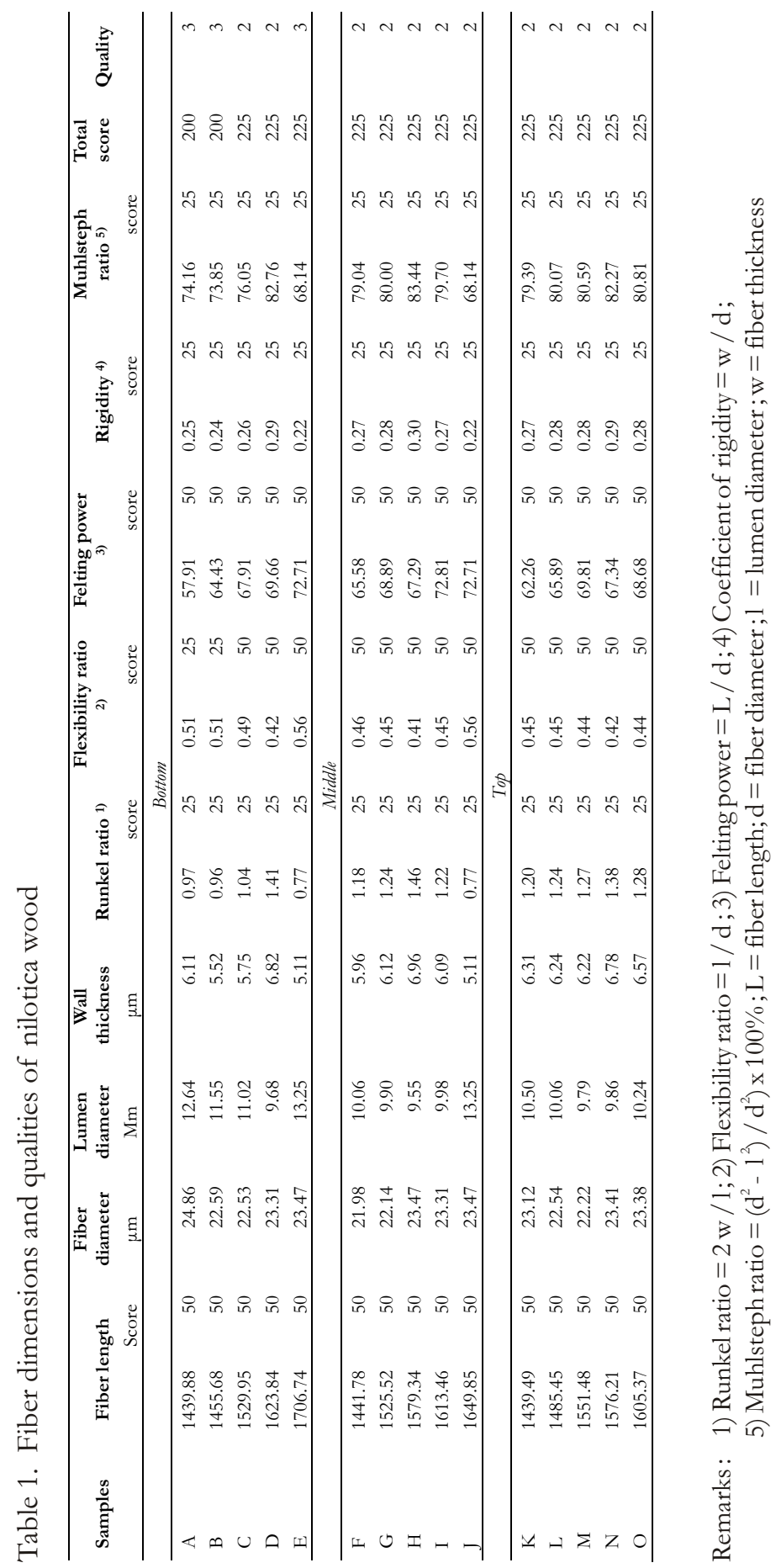




\section{Utilization Possibility}

Prickly acacia is a thorny shrub or small tree that usually grows to $5 \mathrm{~m}$ high but occasionally to $10 \mathrm{~m}$ (Carter and Cowan, 1988). It is usually single-stemmed but may be multi-stemmed at the base (Figure 6). Stem diameter is about $16.5 \mathrm{~cm}$ in 25 years old and the log is classified as small diameter log. Even though, this timber is stiff and hard enough for construction requirements (density about $650-830 \mathrm{~kg} / \mathrm{m}^{3}$ ), however, it is hard to find smooth straight plank from the trees. As a result, this timber is not recommended for construction material.

a.

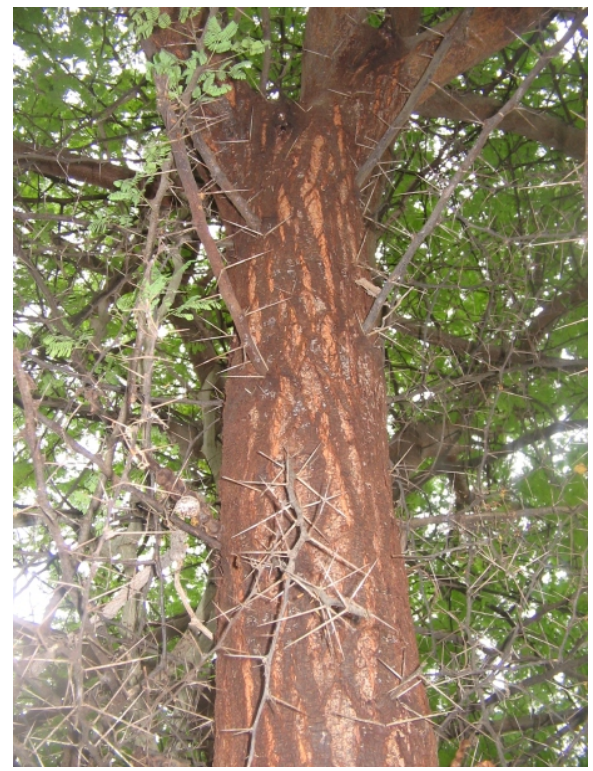

b.

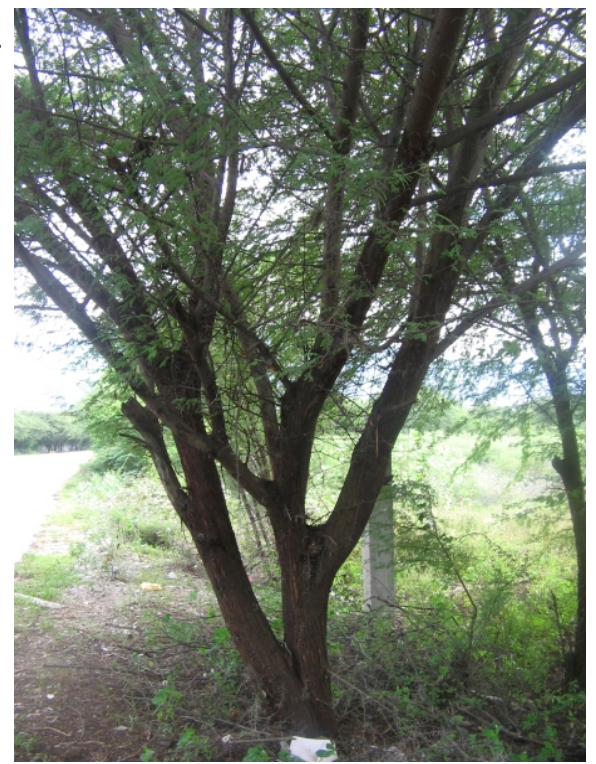

Figure 6 a and b. Acacia nilotica (L.) Willd. stem

The streaky figures of nilotica timber make a good timber product for carving, turnery and boatbuilding. Variation of light and denser fiber cell density gives streaky appearances particularly in tangential surface. Carving of streaky timber gives interesting carved and sculpture products that have high artistically value of art. The streaky appearances gave multilayered looks and bring higher value of turnery products. However, this timber is relatively stiff and hard to work with. As a result, working on wet conditions is recommended.

The calorific value of this timber is relatively high. Carter (1994) reported that calorific value of this timber is around 4,800 - 4,950 kcal $/ \mathrm{kg}$. Goel and Behl (1996) reported that high density, high heat of combustion, low ash, and initial moisture content lead nilotica timber to be a good quality for fuel wood.

Patil et al. (2000) reported that nilotica timber showed high quality charcoal. Nilotica charcoal contents (dry basis) in fixed carbon are $82 \%(\mathrm{db})$, volatile material 15\%, and ash content $5 \%(\mathrm{db})$. Nilotica timber produces charcoal with relatively high fixed carbon and low volatile material. This timber should satisfy for firewood and charcoal manufacture. The excellent firewood and charcoal quality derives the use of nilotica wood for fuel locomotives, river steamers, and boilers in some small industries. 
Fresh bark of nilotica is also a good resource of tannin. Tannins are water soluble high molecular weight polyphenolic compounds and rich in phenolic group. Industrially, tannins are used in the production of leather, adhesive material, dye stuff, and ink. Also, owing to their astringent properties, tannins are used as medicinal materials which promote rapid healing and formation of new tissues on wound and inflamed mucosa (Ayoub, 1982). Mahdi et al. (2006) reported that fresh bark of nilotica contains more than $10 \%$ tannins and was thus suitable for commercial exploitation. The tannin type of nilotica bark is hydrolysablecondensed.

\section{CONCLUSIONS}

1. General characteristic of nilotica timber heartwood is dark brown turning to black which is clearly distinct from reddish brown color of sapwood. The denser cell wall shows attractively streaked in tangential surfaces.

2. The length of wood fiber decreases from pith toward periphery. Longitudinally (axially), higher stem has shorter fiber.

3. Fiber quality of nilotica is in the second class quality, which means wood fiber is moderately thick with narrow lumen diameter.

4. Due to small diameter log with branches, nilotica timber is not recommended for construction material. The timber is suitable for carved and turnery products.

\section{REFERENCES}

Ayoub, S. M. H. 1982. A new molluscicide and algicide from the fruit of Acacia nilotica. Journal of Chemical Technology and Biotechnology 32:728 - 734.

Brenan, J. P. M. 1983. Manual of taxonomy of Acacia species: present taxonomy of four species of Acacia (A. albida, A. senegal, A. nilotica, A. tortilis). FAO Rome. 20-24.

Carter, J. O. 1994. Acacia nilotica: a tree legume out of control. In R.C. Gutteridge and H.M. Shelton (Eds.). Forage tree legumes in tropical agriculture. FAO publication Rome. 338351. Rome.

Carter, J. O. and D. C. Cowan. 1988. Phenology of Acacia nilotica subsp. indica (Berth.) Brenan. In Proceedings of $5^{\text {th }}$ Biennial Conference, Australian Rangelands Society, Longreach, Queensland: 9-12.

Fujii, T. 1989. Vessel characters of Sophora group (Leguminosae). In Proceedings of Wood Anatomy Conference, FPRDI, Philippines: 135-150.

Goel, V. L. and H. M. Behl. 1996. Fuel wood quality of promising tree species for alkaline soil sites in relation to tree age. Biomass and Bio energy 1091:57-61.

Jane, F. W., K. Wilson and D.J.B. White. 1970. The Structure of Wood $2^{\text {nd }}$ edition. Adam and Charles Black. London. 427 pp. 
Mahdi, H., K. Palmina, and I. Glavtch. 2006. Characterization of Acacia nilotica as an indigenous tanning material of Sudan. Journal of Tropical Forest Science 18 (3):181187.

Patil K. N., P. V. Ramana, and R. N. Singh. 2000. Performance evaluation of natural draft based agricultural residues charcoal system. Biomass and Bio energy 18:161-173.

Rachman, A. N. and R. M.Siagian. 1976. Dimensi serat jenis kayu Indonesia. Laporan No.75. Lembaga Penelitian Hasil Hutan, Bogor.

Spies, P. and N. March. 2004. Prickly acacia. National Case Studies Manual. Approaches to the Management of Prickly Acacia (Acacia nilotica subsp. indica) in Australia. Department of Natural Resources, Mines and Energy, The State of Queensland.

Sumayku, R. 2003. Berwisata prihatin ke Baluran. Sinar Harapan, Available from: http://www.sinarharapan.co.id/feature/wisata/2004/0422/wis01.html. Retrieved 06 September 2007.

Tesoro, F. O. 1989. Methodology for Project 8 on Corypha and Livistonia. Forest Products Research and Development Institute, College, Laguna, 4031, Phillipines.

Wheeler, E. A., P. Baas, and P. Gason. 1989. IAWA list of microscopic features for hardwood identification. IAWA Bulletin 10(3):219-332. 